\title{
第21回 群馬移植研究会学術講演会
}

\section{一般演題 I}

座長 須納瀬 豊 (群馬大学医学部第二外科)

1. 腎移植術直後に無尿となった 1 例

田中 俊之, 羽鳥 基明, 蓮見 勝

柏木 文蔵, 鈴木 和浩, 山中 英壽

(群馬大学泌尿器科)

関原 哲夫

(日高病院)

町田 昌己

（公立富岡総合病院）

林 雅道

（古作クリニック東分院）

36 歳, 女性. 血液透析歷 4 年. 平成 14 年 9 月 12 日に 64 歳の父親をドナーとした生体腎移植術を施行. 動脈は 端々, 静脈は端側吻合, 尿管膀胱新吻合は膀胱内吻合法 を用いた. WIT 9 分 30 秒, TIT 73 分 40 秒, 初尿 4 分 10 秒，血尿は認めず．免疫抑制剤はタクロリムス，ステロイ ド,アザチオプリン, バシリキシマブの 4 版併用. 㷌室後 より無尿となった.エコー上, 腎血流は良好, 軽度の水 腎・水尿管症を認め, 原因追求のため再手術を施行. 膀胱 を開き内部を観察すると新尿管口付近および尿管内に血 腫を認め, これらを取り除くと尿り流出を認めた. スプ リントカテーテルを尿管に留置. その後は尿流出良好で あった. 無尿の原因として尿管内の血腫が考えられた。

2. 小腸自家移植による ileocecal junction 運動の変化 荒川 和久, 田中 俊行, 竹吉 泉 富沢 直樹, 村岡 正人, 川手 進 岩波弘太郎, 浜田 邦弘, 須納瀬 豊 大和田 進, 森下 靖雄

（群馬大学第二外科）

持木 彫人 (同第一外科)

【目 的】 犬小腸自家移植モデルを用いて，移植後の ICJ を含めた回盲部運動の変化を検討した.

【方 法】雑種成犬を用いて, 2 段階の手術を行った. 初 めに Strain gauge force transducer を回腸, 上行結腸に縫

\author{
日 時：2003 年 3 月 27 日 (木) 午後 6 時 30 分 \\ 会 場：群馬大学刀城会館 \\ 会長：森下 靖雄 \\ 当番世話人：森下 靖雄 \\ 当番幹事：大和田 進, 竹吉 泉
}

着し, Sleeve sensor 挿入用の cannula を上行結腸に挿入 した. コントロールとして, 空腹期と食後期の運動と ICJ 圧を測定した，次に上腸間膜動静脈周囲の神経・リンパ 管・結合織を切離し, 小腸自家移植モデルを作製した. 同 様の測定を行い, 移植前後で比較・検討した。

【結 果】移植後, 空腹期には移植回腸は IMC cycle の 短縮と phase II が増加し, 終末回腸は IMC cycle の短縮 と phase II の減少がみられた. ICJ 圧は全ての phaseで 低下した. 食後期も, 移植後はICJ 圧の低下がみられ, 終 末回腸の腸内容通過時間も短縮した。

【結 語】小腸移植後, 空腹期および食後期の ICJ 圧の 低下と, 終末回腸の腸内容通過時間が短縮し，これは小 腸移植後の下痢の原因の一部分を担っていると考元られ る.

\section{一般演題 II}

座長 鈴木 秀樹（群馬大学医学部第一外科)

\section{3. 肝細胞癌に対する肝移植の検討}

\section{湯浅 和久, 高木 均, 蘇原 直人 大塚 敏之, 柿崎 暁, 森 昌朋}

(群馬大学肝臓・代謝内科)

【対象及び方法】平成 5 年 12 月より平成 15 年 2 月まで に当科及び関連施設で診療した 5 例の肝細胞癌患者に対 して施行された生体移植について背景, 摘出肝, 経過に ついて比較検討した. 移植施行施設は信州大学第 2 外科, 群馬大学第 1 外科, 同第 2 外科である.

【結 果】年齢は 49 歳から 61 歳で男性が 4 例，女性は 1 例. 全て C 型肝硬变を背景にしておう, Child C, CLIP score 3 点で, 移植適応検討の時点では 5 例ともミラノク ライテリアを満たしていた，肝癌の治療歷のあるものは 4 例でIVR3 例, PEIT1 例, RFA1 例に施行されていた. 摘出肝には最大径 $32 \mathrm{~mm}, 2 \sim 10$ 個の肝癌を認めた. 死亡 は 1 例で術後 5 力月に横隔膜下膿瘍から敗血症に至り亡 
くなった. 残りの 4 例は特に術後 adjuvant chemotherapy などは行なわなかったが, 1 42ヶ月生存しており肝癌 の再発は認めていない.

【結 語】移植理由は肝癌合併例でも肝不全が主体で, 術前ミラノクライテリアを満たす症例も摘出肝ではそれ を逸脱することが多かった. 肝移植は肝癌を伴う肝硬変 患者にも有効な治療といえるが長期予後についてはこれ からの症例の蓄積が必要である.

\section{4. 当科における生体肝移植症例の経験}

一適正な肝重量を考慮したグラフト採取について一 須納瀬 豊, 大和田 進, 武市 卒之 竹吉泉, 川手 進, 岩波弘太郎 浜田 邦弘, 森下 靖雄（群馬大学第 2 外) 笠原 群生, 田中 紘一

(京都大学移植外科)

当科に㧍いて 3 例の生体肝移植症例を経験した. 肝グ ラフトについては, ドナーの予測肝重量を予めCT volumetry で評価し，レシピエントの体重と全身状態を 考慮した上で, 過少肝グラフトにならず，しかもドナー の残肝が不足にならないように設定した. 症例 1 は高シ トルリン血症の 17 歳男性で, ドナーの予測肝重量が $1417 \mathrm{~g}$, レシピエントの体重が $43 \mathrm{~kg}$, グラフト/レシピエ ント体重比 (GRWR) 0.97 で, 肝左葉グラフトとした. 症 例 2 は肝硬変症 (HBV 陽性) の 55 歳女性で, ドナーの予 測肝重量が $1374 \mathrm{~g}$, レシピエントの体重が $48 \mathrm{~kg}$, GRWR 1.85 で, 肝右葉グラフトとした. 症例 3 は原発性肝癌お よび肝硬変症 (HCV 陽性) の 54 歳女性で, ドナーの予測 肝重量が $938 \mathrm{~g}$, レシピ.ナントの体重が $54 \mathrm{~kg}$, GRWR 1.04 で, 拡大肝右葉 (右葉十中肝静脈) グラフトとした。いず れの症例においても, ドナーおよびレシピエントに, 術 後肝不全など肝予備能の低下が原因と思われる合併症を 生じることなく経過した。

\section{5. 成人間生体肝移植における右葉移植の功罪}

野本 健一, 鈴木 秀樹, 金井 伸行
狩野 賢一, 橋本 信次, 岡田 寿之
三原 清香, 加藤 広行, 桑野 博行

(群馬大学第一外科)

【背 景】生体肝移植はその適応を広げ現在では成人間 生体肝移植が多く行われるようになった，その理由のひ とつに右葉移植の導入があった. しかし一方ではドナー の安全性が問われるようになり，欧米に抢けるドナーの 手術における死亡率は $0.3 \sim 0.9 \%$ と言われており, 特に 右葉移植の危険性は問題となってきている. そこで今回, 我々は当科で行ったドナーの手術を左葉と右葉に分けド ナーに対する侵襲を比較検討した。
【対象/方法】当科で行った生体肝移植症例 14 例（左 葉 8 例： $\mathrm{L}$ 群と右葉 6 例 $\mathrm{R}$ 群). 術前因子として年齢, 身 長, 体重等, 術中因子としてグラフト重量, 手術時間, 出 血量等, 術後因子として PT, T-Bil, ALT, AST, 術後在院 日数, 合併症の有無, 医療費等に付き検討した.

【結 果】左葉移植群と右葉移植群にグラフト重量を除 きすべての因子において有意差は認められなかった。

【結 語】我々が行った肝切除症例 124 例で比較検討し た結果 (Hepato-gastroenterology 2002：49.222) とほほ 同様の結果であったが, 右葉移植が増加する傾向にはあ るが，ドナーの安全性を念頭におき残肝重量も念頭にお いた術式を選択し移植を行うべきと考えられた.

\section{一般演題 III}

座長 松島 孝文 (群馬大学医学部第三内科)

\section{6. 成人リンパ性白血病に対する臍帯血移植の 1 例 土岐 典子，斉藤 竜大，入澤 寬之 佐倉 徹, 宮脇 修一}

(群馬県済生会前橋病院血液内科)

症例は 34 歳女性. 急性リンパ性白血病のため, 2002 年 5 月当院入院. 化学療法にて寬解となるも, 再発し, 再寛 解導入療法にて, 完全寛解となった. 予後を考元, 入院時 よりドナー検索を行っていたが, HLA matchドナーは 見つからなかった。御本人の臍帯血移植の希望があり, 2002 年 10 月, $\mathrm{TBI}+\mathrm{CY}$ の前処置にて非血縁者間臍帯血 移植を施行. GVHD 予防は, MTX+FK506 を使用し, 細 胞数は, $3.02 \times 10^{7} / \mathrm{kg}$ で, HLA は 3 座不一致であった。 Day22 に生着し, 急性 GVHD は併発せず, day110 で免 疫抑制㓮を中止した. 慢性 GVHD を皮膚, 口腔内に限局 して認めているが, 現在経過良好で外来通院中である. 小児のみでなく，成人にも多く施行されるようになった 臍帯血移植に関し, 文献的考察を含め報告する.

\section{7. 当院で骨髄非破壊的前処置を用いた造血幹細胞移植 （NST）を行った 5 症例}

\section{齊藤 泰之, 松島 孝文, 河村 俊英 \\ 横濱 章彦, 塚本 憲史, 野島 美久}

(群馬大学医学部第三内科)

\section{前川 出, 唐沢 正光}

(同附属病院輸血部)

\section{半田 寛, 村上 博和 (同保健学科)}

2001 年 3 月から 2 年間で 5 例 (MDS 1, AML 1, Hodgkin 病 1, NHL 1, RCC 1; 年令中央值 53 (21-61) 歳) に対 し血縁ドナ一から骨髄非破壊的前処置を用いた造血幹細 胞移植 (NST) を施行した. 前処置は Fludarabin + Cyclo- 
phosphamideまたはL-PAMを用いた。輸注 CD34 陽性 細胞数中央值は $4.8 \times 106 / \mathrm{kg}$ (3.5-8.0), GVHD 予防は CyA (+sMTX) /FK506で行った. 移植後の白血球最低 中央值は $100(0-300)$, 好中球 $>500$ までの期間中央值は 10 日 (9-21) で, 移植後 100 日以内の早期死亡はなく, 急 性 GVHD を 4 例 (Grade 0-1, Grade 2-4 各 2) で認めた. 抗腫瘍効果は生着不全の 1 例を除く 4 例で認めたが, う ち 1 例はその効果は一過性で原病の再発で死亡した。

【結 語】NST は高齢者, ハイリスク症例でも安全に施 行可能と考えられた.

\section{8. 当科における造血細胞移植36症例の検討}

小川千登世, 金澤 崇, 由上伸一郎

設楽 利二, 松井敦, 霜田 雅史

外松 学, 森川 昭廣 (群馬大学小児科)

近年造血細胞移植は白血病や再生不良性貧血のみなら
ず様々な疾患に対する治療としてその有効性が注目され てきている. 1991 年から 2003 年 3 月までの 12 年間に群 馬大学小児科にて造血細胞移植を行った 36 症例 (38 回) について検討する. 症例は 1 歳から 19 歳の男児 26 例, 女児 10 例, 原疾患注急性白血病 22 例, 若年性骨髄単球 性白血病 2 例, 悪性リンパ腫 5 例, 再生不良性貧血 4 例, その他 (PNET, yolk sac tumor, LCH) 3 例であった. 移 植細胞は自家 3 回, 血縁者間 17 回, 非血縁 17 回, 臍帯血 1 回, 2003 年 3 月現在の粗生存率は $72.2 \%$ あるる. 白血 病等の悪性疾患のうち, 寛解導入不能や再発期のいわゆ 了非寛解期移植症例 9 例中 4 例, 第 3 , 第 4 寛解期の移植 症例 5 例中 2 例が無病生存中であり, 予後不良群にも治 癒が期待される. より強力な免疫抑制を必要とする非血 縁者間移植において, CMV 等のウイルス感染, 再活性化 の合併率が高く,この制御が今後の課題となる. 